\title{
Viability of Heterotrophic Bacteria in Freshwater
}

\author{
By JOHN C. FRY* AND TALAT ZIA \\ Department of Applied Biology, University of Wales Institute of Science and Technology, \\ King Edward VII Avenue, Cardiff CF1 3NU, U.K.
}

(Received 1 April 1982; revised 29 May 198̣2)

The viabilities of planktonic bacteria from nine freshwaters and one raw sewage were compared. Viabilities estimated from microcolony formation in slide culture (18.4-48.7\%) were higher than a conventional plate count method (1.8-14.9\%). Microcolony viability was estimated in four ways; the one recommended was the ratio of the microcolony count and total count of microcolonies and single cells after 24 or $72 \mathrm{~h}$ incubation. Bacterial viability strongly correlated with the percentage of bacteria $<0 \cdot 2 \mu \mathrm{m}^{3}$ in size and the concentration of soluble carbohydrate in the water.

\section{INTRODUCTION}

Plate counts are generally accepted as inadequate for counting all the naturally occurring aquatic bacteria which are viable (Buck, 1979). Many alternative methods have been suggested which fall into two groups. The biochemical methods assess the proportion of active bacteria by counting those which take up radioactive organic materials (Hoppe, 1976; Meyer-Reil, 1978) or which respire (Zimmermann et al., 1978). In the second group are the growth methods which rely on microscopic enumeration during the initial stages of growth in the laboratory. These include techniques which count microcolonies on membrane filters (Jannasch \& Jones, 1959; Kunicka-Goldfinger \& Stronkowska, 1977), microcolonies on agar (Fry \& Zia, 1982) and division-inhibited cells in liquid medium (Kogure et al., 1979). All these methods could be used to assess viability. However, no studies have yet attempted to find the factors which either cause, or are related to, the differences between viability observed in aquatic habitats. This is our aim in the research reported here. For this we use a growth method because there can be no doubt that growing cells are alive, whereas some biochemical function could remain in dead or moribund cells. Also a slide culture technique was selected because it offered substantial advantages over other methods (Fry \& Zia, 1982).

\section{METHODS}

Sampling. Water and sewage samples (1 l) were obtained between June and September 1980. Four samples were taken from each site with approximately one month between each sampling occasion. Sewage samples were obtained from a Cardiff pumping station (Ordnance Survey grid reference, ST 169737) immediately after the sewage had been comminuted. Surface water samples were taken from nine freshwater habitats in South Wales. Three were from flowing waters, polluted mainly with sewage (National Water Council, 1981); these were the R. Rhymney at Draethen (ST 223877), the Afon Llwyd at Llantarnam (ST 308937) and the Taff feeder (ST 179770), a water course connecting the $R$. Taff at Blackweir to Cardiff docks. The other waters were unpolluted and included two mesotrophic water supply reservoirs (Scott, 1975); these were Ynysyfro Old Pond (ST 891285) and Pantyreos Reservoir (ST 258916). Two recreational waters were sampled, namely Roath Park Lake (ST 186794) in Cardiff and a disused section of the Monmouthshire-Brecon Canal at Llantarnam (ST 294922). The remaining two waters were a natural spring, which arose in a stone trough and flowed into a small stream called Nant Draethen (ST 204864), and one of the main drainage channels (reens) on the Monmouthshire levels (ST 268815; Scotter et al.,

Abbreviations: BOD, Biochemical oxygen demand; CPS, casein/peptone/starch medium; PCA, principal component analysis. 
1977). Only the reen, the Monmouthshire-Brecon Canal and Ynysyfro reservoir supported substantial stands of aquatic macrophytes; the other waters were almost devoid of such plants. After transport to the laboratory, samples were stored at $4{ }^{\circ} \mathrm{C}$, shaken for $5 \mathrm{~min}$ by hand and used within $4 \mathrm{~h}$ of collection.

Sample concentration. Where necessary $10 \mathrm{ml}$ samples were concentrated by centrifugation in glass centrifuge tubes with tapered ends at $2000 \mathrm{~g}$ for $20 \mathrm{~min}$ at room temperature $\left(20-22^{\circ} \mathrm{C}\right)$. After centrifugation, 9.7-9.9 ml of the supernatant was removed, the remainder was vortex mixed to resuspend the bacteria and pooled with other concentrated samples.

Medium. Casein/peptone/starch (CPS) agar was used for both slide culture and plate counts. It was prepared as described by Fry \& Humphrey (1978), but for slide culture was filtered through glass fibre filter paper (Whatman $\mathrm{GF} / \mathrm{C})$.

Viable counts by slide culture (microcolonies). Agar coated slides were prepared by allowing $0.5 \mathrm{ml}$ of molten $\left(65^{\circ} \mathrm{C}\right)$ CPS agar to solidify on three-quarters of one side of thin $(0 \cdot 8-1 \mathrm{~mm})$, glass slides sterilized by flaming with $95 \%$ ethanol. Immediately after solifidication, $10 \mu$ l of concentrated water sample was spread on $1 \mathrm{~cm}^{2}$ of the agar and allowed to dry for $10 \mathrm{~min}$ at room temperature. The agar was then covered with a coverslip and incubated at $10^{\circ} \mathrm{C}$ for 24 and $72 \mathrm{~h}$. Numbers of microcolonies, which consisted of two or more bacteria, and single cells were counted before or after incubation with a Zeiss Universal microscope using either a $63 \mathrm{X}$ planapochromat (numerical aperture, NA $=1.4$ ) or a $100 \mathrm{X}$ neofluor $(\mathrm{NA}=1 \cdot 3$ ) oil immersion objective with phase contrast microscopy. Full details of the slide culture methodology are discussed elsewhere (Fry \& Zia, 1982).

Viable counts on agar plates (macrocolonies). Samples were serially diluted in CPS medium without agar before plate counts were performed by the spotting method of Bousfield et al. (1973). Five samples $(10 \mu \mathrm{l})$ of each dilution were put on to the surface of agar plates, allowed to dry and incubated at $18{ }^{\circ} \mathrm{C}$ for $8 \mathrm{~d}$. After incubation, the number of macrocolonies in drops which contained between 2 and 20 colonies were counted.

Epifluorescence microscopy. Total counts of bacteria were obtained by an acridine orange epifluorescence method (Jones, 1979). A final concentration of acridine orange of $5 \mathrm{mg} \mathrm{l}^{-1}$ was used to stain the bacteria for $3 \mathrm{~min}$ and filtration was through $0.2 \mu \mathrm{m}$ pore size black Sartorius membrane filters. A Zeiss Universal microscope with two BG-12 exciter filters and a barrier filter 50 using a $63 \mathrm{X}(\mathrm{NA}=1 \cdot 4)$ or a $100 \mathrm{X}(\mathrm{NA}=1 \cdot 25)$ oil immersion lens was used to count $100-400$ red or green fluorescing bacterially shaped objects. Bacteria on three replicate membrane filters were counted in each sample.

Calculations of viability. Estimates of microcolony viability $\left(V, V_{\mathrm{o}}, V_{\mathrm{e}}, V_{\mathrm{t}}\right)$ and macrocolony viability $\left(V_{\mathrm{v}}\right)$ were calculated as follows: $V=m_{\mathrm{t}} / t_{0} ; V_{0}=\left(m_{\mathrm{t}}-m_{0}\right) / t_{0} ; V_{\mathrm{e}}=\left(m_{\mathrm{t}}-m_{0}\right) / t_{\mathrm{e}} ; V_{\mathrm{t}}=m_{\mathrm{t}} / t_{\mathrm{e}} ; V_{\mathrm{v}}=c / t_{\mathrm{e}}$ where $m_{0}=$ the number of microcolonies before incubation, $m_{\mathrm{t}}=$ the number of microcolonies after incubation, $t_{0}=$ the total count of single cells and microcolonies before incubation, $t_{\mathrm{e}}=$ the total count of bacteria by epifluorescence microscopy and $c=$ the plate count. To estimate $V_{\mathrm{e}}, V_{\mathrm{t}}$ and $V_{\mathrm{v}}$ all parameters in the equations had to be calculated as a number per unit volume. This was simply done for $t_{\mathrm{e}}$ and $c$, but for $m_{\mathrm{t}}$ and $m_{0}$ the estimates had to be corrected for losses of bacteria during centrifugation. This was determined from total counts by epifluorescence microscopy of the original and concentrated water samples. Viabilities were converted to percentages.

Cell size estimation. Bacteria were concentrated in $0.5 \%(\mathrm{v} / \mathrm{v})$ formaldehyde (Powell \& Errington, 1963) leaving $0.1 \mathrm{ml}$ in each glass centrifuge tube. Although formalin might cause shrinkage of bacteria, its use is essential to prevent the enlargement of small cells which occurs on agar (Torrella \& Morita, 1981). The concentrate $(10 \mu l)$ was spread over approximately $0.5 \mathrm{~cm}^{2}$ of the surface of an agar coated slide, allowed to dry, covered with a coverslip and examined under phase contrast microscopy, as described for slide culture. Black and white photographs were taken using an Olympus OM-2 camera. Developed negatives $(36 \mathrm{~mm} \times 24 \mathrm{~mm}$ ) were viewed with a slide projector and the length and diameter of all the bacteria which were within a constantly placed central section (12 mm $\times$ $8 \mathrm{~mm}$ ) of the negative were measured. Measurements were made of the first 100-150 bacteria that were observed. Absolute sizes were calculated from the proportions of a similarly projected negative of a slide micrometer. The cell volume of the fixed cells was calculated assuming them to be parallel sided cylinders with hemispherical ends using the formula:

$$
\text { cell volume }=\left[d^{2}(\pi / 4)\right](1-d)+\pi d^{3} / 6
$$

where $d$ was the cell diameter and 1 was the length. This photographic method correlated well $(r=0.88 ; P<$ $0.001)$ with the classical method of size measurement using an ocular micrometer (Salonen, 1977).

Biochemical oxygen demand (BOD). The method of Taras et al. (1971) was used with the reagents of Golterman \& Clymo (1969) and a back titration procedure (Talling, 1973) to assess the oxygen concentration. BOD measurements were made using aerated membrane-filtered water as diluent.

Estimation of soluble carbohydrate and protein. The dissolved materials in 11 of $0.2 \mu \mathrm{m}$ filtered water and sewage were concentrated by rotary evaporation at $50{ }^{\circ} \mathrm{C}$ under reduced pressure to approximately $10 \mathrm{ml}$. Soluble carbohydrates in the concentrated samples were measured by the phenol/sulphuric acid method (Gerchakov \& Hatcher, 1972) using glucose as the calibration standard. The Lowry method was used to estimate the soluble protein in concentrated samples using bovine serum albumin as standard. 
Statistical analysis. Means were compared by analysis of variance and differences between means were assessed with the least significant range procedure (Sokal \& Rohlf, 1969). Percentages were transformed by arcsin $\sqrt{x / 100}$ and other variables by $\log _{10} x$. These transformations ensured normality of distribution and homogeneity of variances; the $F_{\max }$ and Bartlett's test were used to test for the latter condition. Confidence intervals and coefficients of variation were calculated on untransformed and transformed data, respectively. These tests and principal component analysis (PCA) were performed with the Statistical Package for the Social Sciences (Nie et al., 1975; Hull \& Nie, 1979). PCA was performed with subprogram FACTOR using PA1. Multiple regression was performed with Minitab (Ryan et al., 1976) using transformed data unless otherwise stated. All significant differences between means and the significance of correlation coefficients are quoted for $P<0.05$ unless otherwise stated. The squared correlation coefficient $\left(r^{2}\right)$ and the squared multiple correlation coefficient $\left(R^{2}\right)$ were used to describe the percentage variability explained by regression.

\section{RESULTS}

\section{Comparison of methods for estimating viability}

Viabilities of bacteria from ten sites show (Table 1) that estimates based solely on the microcolony method $\left(V_{0}\right)$ were highest. Estimates which used microcolony and epifluorescence counts $\left(V_{\mathrm{e}}\right)$ were lower because the total counts of bacteria obtained by the microcolony method $\left(t_{0}\right)$ were less $(55.7 \pm 1.6 \%$; Table 2$)$ than those obtained by epifluorescence $\left(t_{\mathrm{e}}\right)$. The lowest results were for the macrocolony viability $\left(V_{\mathrm{v}}\right)$, which were significantly lower than the other estimates at all but one site. Microcolony counts after $72 \mathrm{~h}$ incubation were not possible in almost all samples from the Taff feeder, R. Rhymney, Afon Llwyd and Nant Draethen spring. Hence, at these sites the optimum incubation time was $24 \mathrm{~h}$. All other sites had optima after $72 \mathrm{~h}$ incubation. The three polluted waters and Nant Draethen spring showed the highest viabilities

\section{Table 1. Percentage viabilities obtained by slide culture and colony counts at ten sites}

Slide cultures were incubated at $10^{\circ} \mathrm{C}$ for $24 \mathrm{~h}$ or $72 \mathrm{~h}$ and colony counts were made by a drop procedure incubated at $18^{\circ} \mathrm{C}$ for $8 \mathrm{~d}$; both used CPS medium. The values represent means of four samples taken at monthly intervals unless otherwise stated.

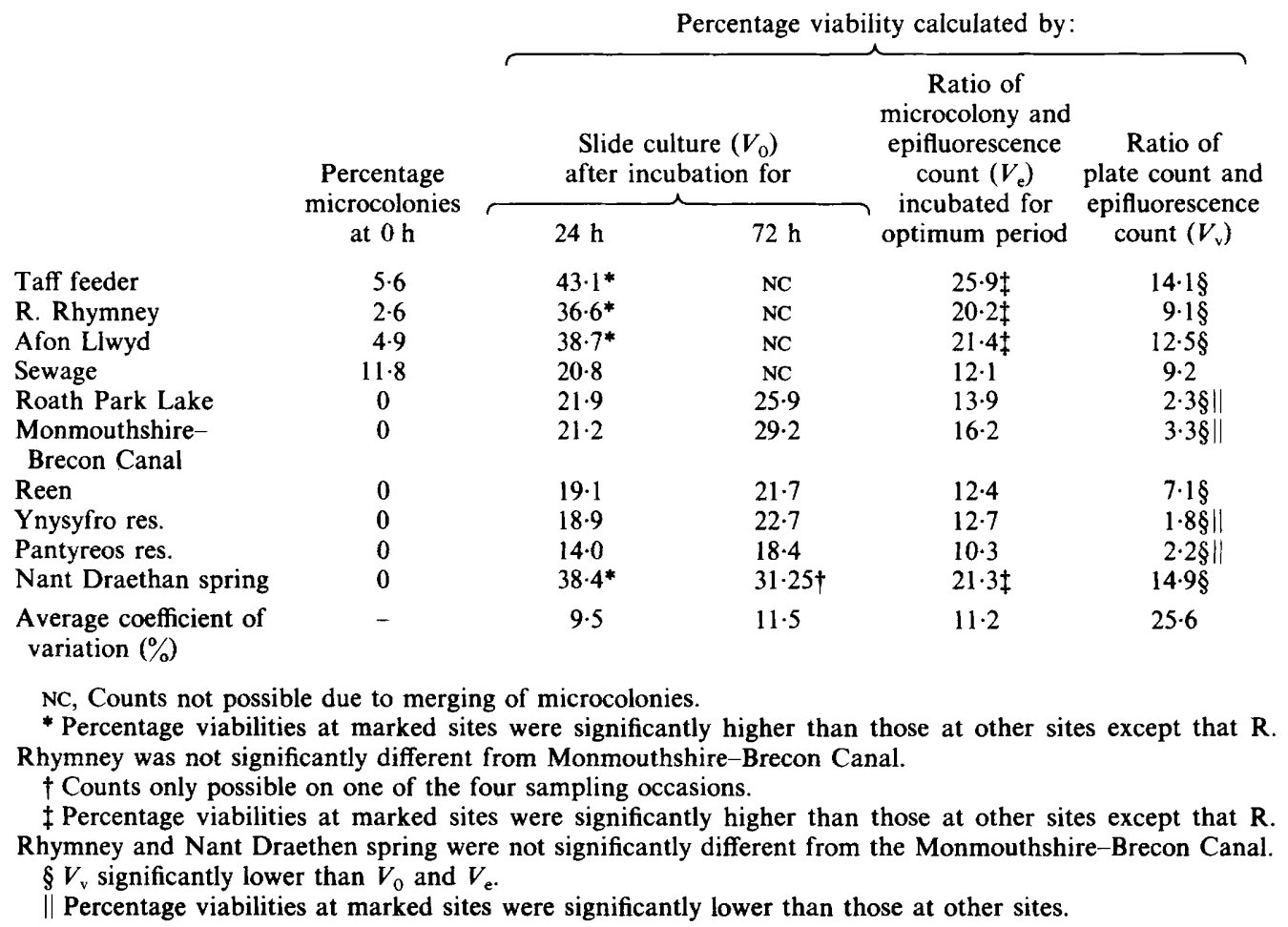




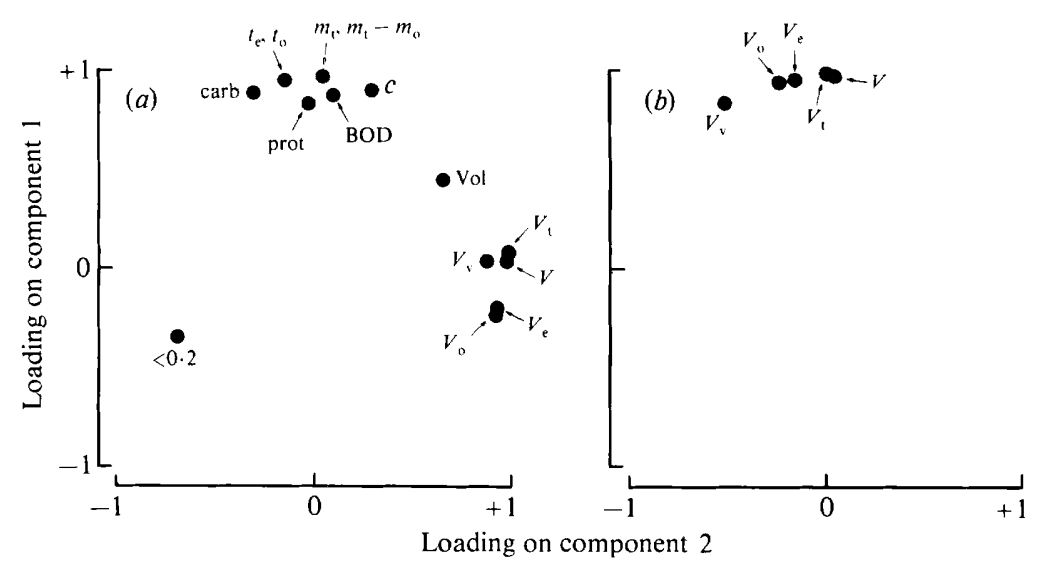

Fig. 1. Principal component analysis solutions of the first two components for $(a)$ all the variables used in this study and $(b)$ the viability estimates only, using data from all sites. The abbreviations are defined in Methods, except the following: carb, soluble carbohydrate; prot, soluble protein; vol, mean bacterial volume; $<0 \cdot 2$, bacteria $<0 \cdot 2 \mu \mathrm{m}^{3}$ in size.

with all three methods. The polluted waters and sewage were the only sites having microcolonies present before incubation $\left(m_{0}\right) . V$ was calculated by adding $V_{0}$ and $m_{0}$, and $V_{\mathrm{t}}$ was a combination of $V_{\mathrm{e}}$ and $m_{0}$. Thus $V$ and $V_{\mathrm{t}}$ were highest in the polluted waters, Nant Draethen spring and sewage. In these waters $V$ ranged from $32.6 \%$ to $48.7 \%$ and $V_{\mathrm{t}}$ ranged from $19.0 \%$ to $28.4 \%$.

Despite these differences the viabilities were very highly corrrelated with each other; this correlation was stronger for the microcolony viabilities $\left(r^{2}=81-98 \%\right)$ than for the macrocolony viability $\left(r^{2}=50-66 \%\right)$. PCA clearly showed these relationships (Fig. 1) as the viabilities were tightly grouped whether other variables were present (Fig. $1 a$ ) or absent (Fig. $1 b$ ). In the latter solution the first two components explained $96 \%$ of the data's variability and the viabilities were in three closely related groups. The macrocolony viability $\left(V_{\mathrm{v}}\right)$ was separated from the microcolony viabilities, which were tightly grouped with $V_{0}$ close to $V_{\mathrm{e}}$ and $V_{\mathrm{t}}$ close to $V$. As the microcolony viabilities were so closely related, only one should be selected for further study. $V_{\mathrm{e}}$ and $V_{\mathrm{t}}$ were difficult to estimate because microcolony and epifluorescence total counts had to be related and this needed extra counts to allow for losses of bacteria during centrifugation. $V_{0}$ needed an estimate of the number of microcolonies present at zero time. Consequently, in the remaining results $V$ will be the microcolony viability used, because it was simplest to estimate, and will be compared with the more traditional macrocolony viability $\left(V_{\mathrm{v}}\right)$.

\section{Comparison of viabilities and other variables}

Population estimates and sizes of bacteria, together with values of BOD, soluble protein and soluble carbohydrate at all sites are given in Table 2 . The viable counts were lower than both of the total counts, the microcolony counts $\left(m_{\mathrm{t}}-m_{0}\right)$ being highest. There were significant differences between the sites for all variables. Sewage was significantly different from all other sites having the highest bacterial populations and values for the chemical variables. Sewage also contained the largest cells and had the lowest proportion of small cells. Nant Draethen spring water was also significantly different from the other sites with the lowest values for bacterial populations and chemical variables; however, its bacteria did not have the smallest mean volume, but they had the highest proportion of small cells. The values of all variables at all other sites fell between these two extremes, but showed no clear pattern, although most values for the Taff feeder, Roath Park Lake, the Monmouthshire-Brecon Canal and the reen site were higher than the rest.

The differences in the cell sizes can be seen in the typical frequency histograms of cell volumes (Fig. 2). They showed that the unpolluted sites such as Pantyreos and Ynysyfro reservoirs had 


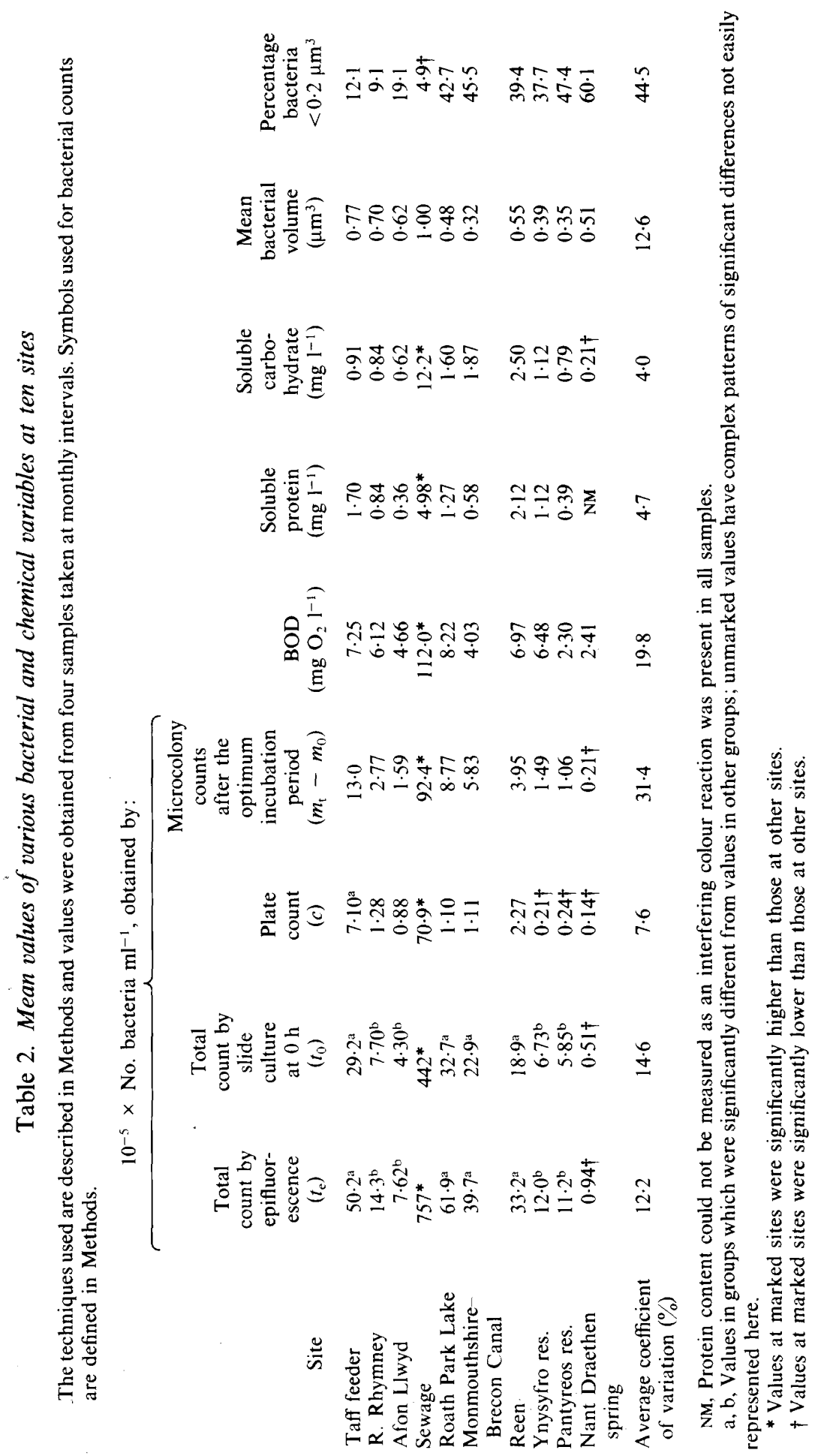




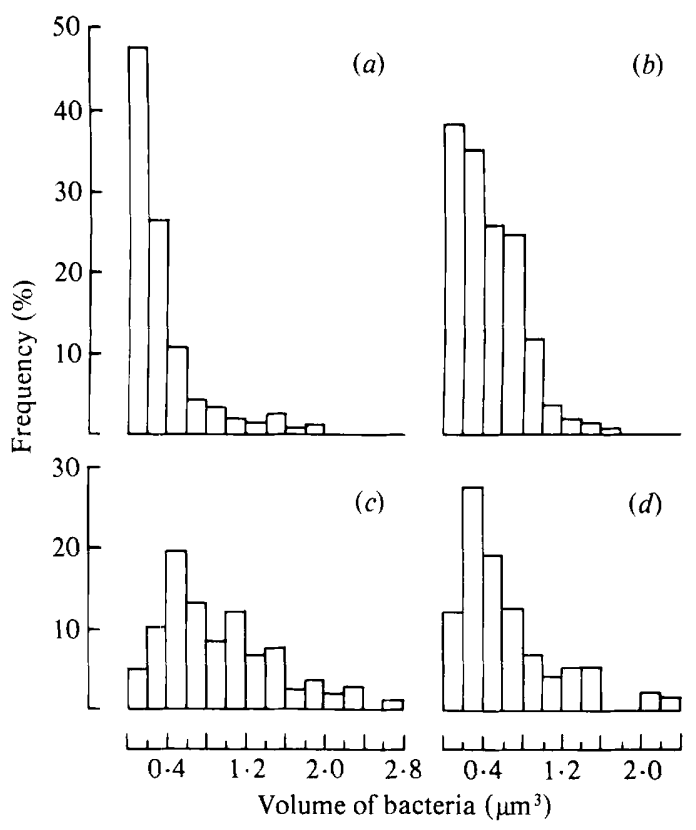

Fig. 2. Frequency histograms of bacterial volumes from (a) Pantyreos reservoir, (b) Ynysyfro reservoir, (c) sewage and $(d)$ Taff feeder water samples.

frequency distributions skewed very heavily to the left whilst those of the polluted sites were less skewed. This meant that unpolluted sites had bacteria with smaller mean volumes and most cells in the $0-0 \cdot 2 \mu \mathrm{m}^{3}$ class, whilst polluted sites had higher mean volumes and few small cells. The smallest bacteria observed at the different sites varied between 0.02 and $0.08 \mu \mathrm{m}^{3}$ and the largest between 1.51 and $6.07 \mu \mathrm{m}^{3}$.

The types of organisms and microcolonies observed by slide culture during this work were similar to those reported previously (Fry \& Zia, 1982). In the samples from Roath Park Lake about $5 \%$ of the bacteria were prosthecate forms resembling Planctomyces spp. Also, in samples from Pantyreos and Ynysyfro reservoir 5-7\% of the bacteria were loosely aggregated clumps of pleomorphic rod-shaped bacteria. Neither of these distinct morphological types multiplied during incubation.

Further statistical analysis was required to determine the relationship that existed between the viabilities and other variables. The value of many variables in sewage was very high (Table 2 ), hence the analyses were performed both with and without the sewage results. This was necessary to check that these high values were not forcing linear relationships upon the data.

Correlation analysis (Table 3 ) between viability and the other variables gave similar results whether the sewage samples were included or omitted. The highest coefficients were with the cell size estimates, but these relationships only accounted for between 29 and $46 \%$ of the data's variability. The only other consistently significant coefficients were with the plate counts and soluble carbohydrate, which accounted for less variability $(16-25 \%)$. There were few other significant correlations. The size variables were poorly correlated with population estimates and chemical variables; these correlations were rarely significant and never accounted for more than about $15 \%$ of the data's variability. The population estimates and chemical variables were all significantly correlated with each other, but no obvious pattern in the coefficients was evident.

PCA objectively confirmed these observations, revealed other relationships and provided similar solutions whether sewage was included (Fig. 1) or omitted. In the solution with all the data (Fig. $1 a$ ) the first two components accounted for $85 \%$ of the variability and the other components did not add to the explanation. This solution shows all the population and chemical 

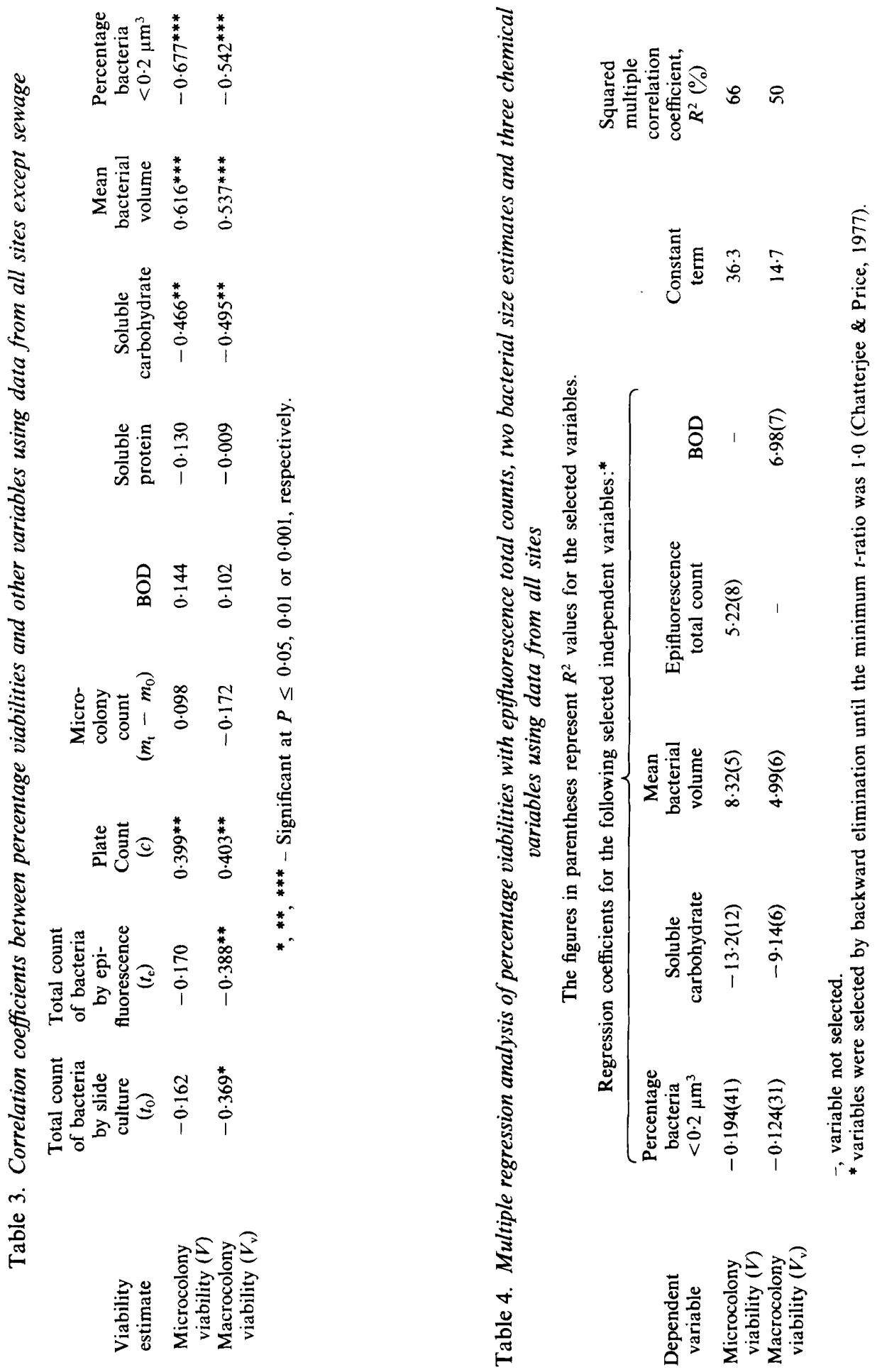
variables to be closely grouped and loading very heavily (average $=0.925$ ) on component one with the viability estimators loading equally highly (average $=0.93$ ) on component two. The size variables also loaded heavily on component two, which were thus closely related to the viabilities. All other variables were close to zero on component two, but the plate count and soluble carbohydrate were furthest from zero, a reflection of the significant correlations between these variables and the viabilities (Table 3).

PCA of the independent variables used for the multiple regression (Table 4) showed that the data was multicollinear, because several eigenvalues were very small (Chatterjee $\&$ Price, 1977). Despite this condition the multiple regression solution was reliable. Similar solutions were obtained with transformed or untransformed data using stepwise or backward elimination procedures, and the regression coefficients changed little from step to step during variable selection. In both solutions four variables were selected, but two of these variables accounted for most of the variability explained by the equations $(72 \& 80 \%)$. Hence both viabilities were influenced predominantly by the percentage of bacteria smaller than $0.2 \mu \mathrm{m}^{3}$ and the soluble carbohydrate.

\section{DISCUSSION}

The main method of estimating viability used here, with microcolony counts and slide culture, proved satisfactory and straightforward. The method always gave viability estimates much larger than the macrocolony technique $\left(V_{\mathrm{v}}\right)$. This agrees with other research which has shown that microcolony counts on membrane filters (Jannasch \& Jones, 1959; Straskrabova, 1973; Kunicka-Goldfinger \& Stronkowska, 1977) and division inhibition techniques (Kogure et al., 1979) are superior to the traditional plate count. Slide culture is likely to be better than these other techniques as it is easier to use than membrane filtration and should be more realistic than the inhibition method as no inhibitors are used. Our slide culture is also likely to be superior to that of Torrella \& Morita (1981) as we use a thinner layer of agar, which allows a better phase contrast image and avoids excessive concentration of the inoculum which leads to overgrowth of small microcolonies by large ones. As in previous work (Fry \& Zia, 1982) the current experiments found the optimum incubation time varied between sites, so a single incubation time still cannot be recommended.

The inclusion of the microcolonies present at zero time in the calculation of viability is problematical. Their exclusion will prevent overestimates of viability. However, their inclusion makes viability estimates by slide culture much easier as an initial count does not have to be made. The only waters which had microcolonies at $0 \mathrm{~h}$ were from polluted sites, containing large bacteria which are more likely to be viable (Tempest et al., 1967; Hoppe, 1976). Also, counts of cell pairs in aquatic bacterial populations have been used to estimate growth rates (Brock, 1971; Hagstrom et al., 1979; Newell \& Christian, 1981). Thus, microcolonies present before incubation are likely to be viable and so our omission of the zero time microcolony count when estimating viability as $V$ seems reasonable. In further work $V$ could be estimated from the ratio of the microcolony count and the total count of microcolonies and single cells after incubation as this would avoid any observation before incubation. This is possible because on CPS microcolonies or single cells are not lost during incubation (Fry \& Zia, 1982). Consequently, we recommend this for routinely estimating microcolony viability.

The close association between the population densities and chemical variables noted here agree with the popular belief that the size of bacterial populations depends on the fertility, and hence the carbon content, of their aquatic habitat (Wetzel, 1975). In particular, the relationships observed with BOD correspond very well with those between BOD, direct counts, colony counts and microcolony counts found for a similar range of waters by Straskrabova (1968). Consequently, the results presented here probably have general relevance to freshwater habitats. In particular, the strong relationship between the viabilities and both the percentage of small cells and the soluble carbohydrate, rather than the population estimates or other chemical variables, is probably generally applicable. It cannot be said from the evidence presented whether this relationship is causal. The soluble carbohydrate is probably related to the 
concentration of available carbon in the water and hence causally related to viability. The proportion of small cells might be related to growth rate, as it is in pure cultures (Tempest et al., 1967), which in turn could cause changes in viability.

Marine and estuarine bacteria are reported to be very small, with average volumes ranging from about 0.05 to $0.19 \mu^{3}$ (Hoppe, 1976; Bowden, 1977; Wilson \& Stevenson, 1980). Freshwater bacteria are also small, averaging $0.015-0.24 \mu^{3}$ (Salonen, 1977; Krambeck et al., 1981). The mean volumes reported here are considerably larger $\left(0 \cdot 32-1 \cdot 0 \mu \mathrm{m}^{3}\right)$. This discrepancy could in part result from differences in preparation procedures before size estimation or from our use of fairly nutrient-rich sites. It is possible that the smallest bacteria were lost during centrifugation as Torrella \& Morita (1981) believe. However, we have observed bacteria as small as $0.02 \mu \mathrm{m}^{3}$ in our samples, so such losses cannot completely explain our large average sizes.

The strong link between cell size and viability, which we have demonstrated, concurs with suggestions from other workers that small aquatic bacteria are dormant (Stevenson, 1978) and are unculturable (Hoppe, 1976). Consequently, it might be only the large bacteria in our samples that formed microcolonies. This theory seems tenable from a comparison of the viabilities (Table 1) and the percentage of small cells (Table 2). However, it is probably an oversimplification as microcolonies of both small and large cells are observed with slide culture (Torrella \& Morita, 1981; Fry \& Zia, 1982). An alternative theory is that the natural aquatic bacteria have evolved to be resistant to starvation by becoming very small with a minimum maintenance requirement and turnover of cell components. They might coincidentally become very difficult to culture by, for example, becoming particularly susceptible to substrateaccelerated death (Postgate, 1967) or similar phenomena. Many reports support this theory. Examples are the discovery of small, starvation-resistant mutants of Klebsiella aerogenes (Harrison \& Lawrence, 1963), the lysine-accelerated death observed in a marine isolate of Alteromonas esperjiana, which was also starvation resistant (Chan, 1977), and the ability of many small, marine bacteria to form colonies of large cells on rich media (Torrella \& Morita, 1981).

We are grateful to the Government of Pakistan for the award of a Ministry of Education Central Overseas Training Scholarship to Talat Zia which supported her during this work.

\section{REFERENCES}

Bousfield, I. J., Smith, G. L. \& Trueman, R. W. (1973). The use of semi-automatic pipettes in the viable counting of bacteria. Journal of Applied Bacteriology 36, 297-299.

BowDEN, W. B. (1977). Comparison of two directcount techniques for enumerating aquatic bacteria. Applied and Environmental Microbiology 33, 1229 1232.

BRock, T. D. (1971). Microbial growth rates in nature. Bacteriological Reviews 35, 39-58.

Buck, J. D. (1979). The plate count in aquatic microbiology. In Native Aquatic Bacteria: Enumeration, Activity and Ecology, pp. 19-28. Edited by J. W. Costerton \& R. R. Colwell. Philadelphia : American Society for Testing and Materials.

CHAN, K. (1977). Responses of marine bacteria to nutrient addition and secondary heat stress in relation to starvation. Microbios Letters 6, 137 144.

Chatterjee, S. \& Price, B. (1977). Regression Analysis by Example. New York: John Wiley.

FrY, J. C. \& HumphreY, N. C. B. (1978). Techniques for the study of bacteria epiphytic on aquatic macrophytes. In Techniques for the Study of Mixed Populations, pp. 1-29. Edited by D. W. Lovelock \& R. Davies, London: Academic Press.
FRY, J. C. \& ZIA, T. (1982). A method for estimating viability of aquatic bacteria by slide culture. Journal of Applied Bacteriology 53, (in the Press).

Gerchakov, S. K. \& Hatcher, P. G. (1972). Improved technique for the analysis of carbohydrates in sediments. Limnology and Oceanography 17, 938943.

Golterman, H. L. \& Clymo, R. S. (1969). Methods for the Chemical Analysis of Fresh Water, IBP Handbook No. 8. Oxford: Blackwell.

Hagstrom, A., Larsson, U., Horstedt, P. \& NorMARK, S. (1979). Frequency of dividing cells, a new approach to the determination of bacterial growth rates in aquatic environments. Applied and Environmental Microbiology 37, 805-812.

Harrison, A. P. \& Lawrence, F. R. (1963). Phenotypic, genotypic and chemical changes in starving populations of Aerobacter aerogenes. Journal of Bacteriology 85, 742-750.

HOPPE, H. G. (1976). Determination and properties of actively metabolising heterotrophic bacteria in the sea, investigated by means of micro-autoradiography. Marine Biology 36, 291-302.

Hull, C. H. \& NiE, N. H. (1979). SPSS Update: New Procedures and Facilities for Releases 7 and 8 . New York: McGraw-Hill. 
JANNASCH, H. W. \& JoNES, G. E. (1959). Bacterial populations in sea water as determined by different methods of enumeration. Limnology and Oceanography 4, 128-139.

JoNES, J. G. (1979). A Guide to Methods of Estimating Microbial Numbers and Biomass in Freshwater, Freshwater Biological Association Scientific Publication No. 39. Windermere: Freshwater Biological Association.

Kogure, K., Simidu, U. \& TAGA, N. (1979). A tentative direct microscopic method of counting living marine bacteria. Canadian Journal of Microbiology 25, 415-420.

KrambeCK, C., Krambeck, H. \& OverbeCK, J. (1981). Microcomputer-assisted biomass determination of planktonic bacteria on scanning electron micrographs. Applied and Environmental Microbiology 42, 142-149.

Kunicka-Goldfinger, W. \& Stronkowska, E. (1977). Determination of the number of active saprophytic aquatic bacteria by semi-continuous culture on membrane filters. Acta microbiologica polonica 26, 199-205.

MEYER-REIL, L. A. (1978). Autoradiography and epifluorescence microscopy combined for determination of number and spectrum of actively metabolizing bacteria in natural waters. Applied and Environmental Microbiology 36, 506-512.

National Water Council (1981). River Quality: the 1980 Survey and Future Outlook. London: National Water Council.

Newell, S. Y. \& Christian, R. R. (1981). Frequency of dividing cells as an estimator of bacterial productivity. Applied and Environmental Microbiology 42, 23-31.

Nie, N. H., Huli, C. H., Jenkins, J. G., SteinbrenNER, K. \& BENT, D. H. (1975). Statistical Package for the Social Sciences, 2nd edn. New York : McGrawHill.

Postgate, J. R. (1967). Viability measurements and the survival of microbes under minimum stress. Advances in Microbial Physiology 1, 1-23.

Powell, E. O. \& Errington, F. P. (1963). The size of bacteria as measured with the Dyson image-splitting eyepiece. Journal of the Royal Microscopical Society 82, 39-49.

RYaN, T. A., JoINTER, B. L. \& RYAN, B. F. (1976). Minitab Student Handbook. North Scituate, U.S.A.: Duxbury Press.

SAlONEN, K. (1977). The estimation of bacterioplankton numbers and biomass by phase contrast microscopy. Annales botanici fennici 14, 25-28.
Scort, R. N. (1975). Studies on some Welsh reservoirs with special reference to Talybont reservoir. In The effects of Storage on Water Quality, pp. 203-238. Medmenham: Water Research Centre.

Scotter, C. N. G., Wade, P. M., Marshall, E. J. P. \& EDWARDS, R. W. (1977). The Monmouthshire levels' drainage system: its ecology and relation to agriculture. Journal of Environmental Management 5, 75-86.

SoKal, R. R. \& RohlF, F. J. (1969). Biometry. San Francisco: W. H. Freeman.

Stevenson, L. H. (1978). A case for bacterial dormancy in aquatic systems. Microbial Ecology 4, 127-133.

STRASKRaBOVA, V. (1968). Bakteriologische Indikation der Wasserverunreinigung mit abbaubaren Stoffen. Limnologica (Berlin) 6, 29-36.

STRASKRABOVA, V. (1973). Methods of counting water bacteria. Comparison and significance. Acta hydrochimica hydrobiologica 1, 433-454.

TALLING, J. F. (1973). The application of some electrochemical methods to the measurement of photosynthesis and respiration in freshwaters. Freshwater Biology 3, 335-362.

Taras, M. J., Greenberg, A. E., Hoak, R. D. \& RAND, M. C. (1971). Standard Methods for the Examination of Water and Waste Water, 13th edn, pp. 489-495. Washington D.C. : American Public Health Association.

Tempest, D. W., Herbert, D. \& Phipps, P. J. (1967). Studies on the growth of Aerobacter aerogenes at low dilution rates in a chemostat. In Microbial Physiology and Continuous Culture, 3rd International Symposium, pp. 240-254. Edited by E. O. Powell, C. G. T. Evans, R. E. Strange \& D. W. Tempest. London : HMSO.

Torella, F. \& Morita, R. Y. (1981). Microcultural study of bacterial size changes and microcolony and ultramicrocolony formation by heterotrophic bacteria in seawater. Applied and Environmental Microbiology 41, 518-527.

Wetzel, R. G. (1975). Limnology. Philadelphia: W. B. Saunders.

Wilson, C. A. \& Stevenson, L. H. (1980). The dynamics of the bacterial population associated with a salt marsh. Journal of Experimental Marine Biology and Ecology 48, 123-138.

ZimmermanN, R., ItURRIAGA, R. \& BeckeR-BiRK, J. (1978). Simultaneous determination of the total number of aquatic bacteria and the number thereof involved in respiration. Applied and Environmental Microbiology 36, 926-935. 